\title{
フレッシュコンクリートのせん断変形特性に関する実験的研究 EXPERIMENTAL INVESTIGATION ON SHEAR DEFORMATION OF FRESH CONCRETE
}

\author{
李 柱 国*, 李 潔 勇** \\ Zhuguo LI and Jieyong LI
}

\begin{abstract}
The clarification and modeling of fresh concrete's rheological performance is basically needed for realizing the workability design of fresh concrete. In this study we investigated experimentally the shear deformation of cementitious materials in fresh state using a stress growth method, and discussed the effects of fluidity, vertical pressure, loading rate, maximum size of particle, and volume concentration of solid particle. Then, we proposed a deformation model to describe the free deformation property of fresh concrete under shear stress. As a result, fresh concrete's shear deformation would experience suspension state, visco-elsto-plastic state and shear failure state with increasing shear stress, ant it shows different features in different stress state due to particles' contacts and dilatancy. Also, the fluidity of specimen and the vertical pressure produce great effects on the shear strain/ rate-shear stress relationships.
\end{abstract}

Keywords : Fresh concrete, Shear deformation, Stress controlled method, Stress state, Dilatancy フレッシュコンクリート, せん断変形, 応力制御試験法, 応力状態, ダイラタンシー

\section{1. はじめに}

コンクリートのワーカビリティーは、その打込みおよび硬化後の品 質に大きな影響を与える。ワーカビリティーは、運搬・打込み・締固 め・仕上げなどのフレッシュコンクリートの移動・変形を伴う作業の 容易さと、それらの作業によってもコンクリートの均一性が失われな いような総合的な性質であると定義されている ${ }^{1}$ 。したがって、良好 なワーカビリティーを有するために、コンクリートは、施工方法と部 材条件に応じた適切な変形抵抗性と分離抵抗性を有する必要がある。 しかし、現在、ワーカビリティーの評価、照査技術はまだなく、フレ ッシュコンクリートの品質は、図 1 に示すように、流動性の程度を表 すスランプやスランプフローのみによって規定されている。

近年、コンクリートのフレッシュ性状が混和材料や再生材料など の使用によって複雑化・多様化しており、スランプやスランプフロ 一によって正確に評価できないケースが少なくない。また、建物の 大型化・高層化およびポンプ車の性能向上に伴い、コンクリートの

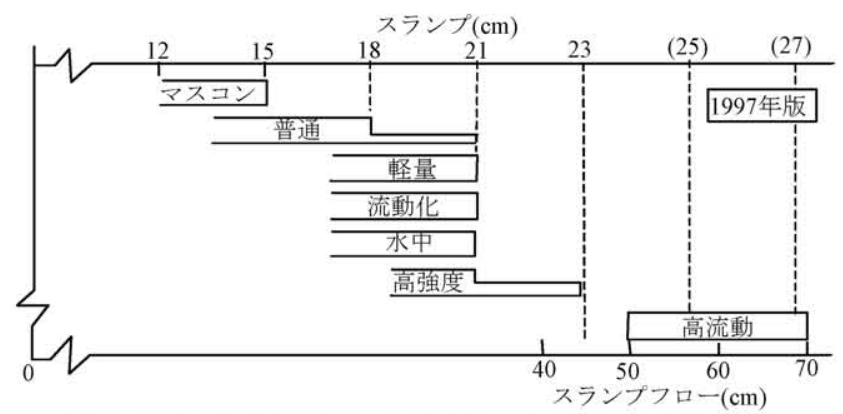

図 1 JASS 5 に規定されている各種コンクリートの流動性 ${ }^{11}$
ポンプ圧送の速度・高度・距離は増大してきている。さらに、建物 の高層化と耐震性能の確保のために、鉄筋が密に配置されて、コン クリートの打込みの難度が増してきている。このため、フレッシュ コンクリートの品質の評価、設定および適合性判定は、今までの経 験則や仕様書では対応しにくくなっている。そこで、施工方法と部 材条件に基づいてフレッシュコンクリートの品質を設定・判定する 施工設計法の確立が極めて重要であると考えられる ${ }^{2)}$ 。

図 2 は、谷川・森が 1988 年に提唱した数值シミュレーションに基 づいた施工設計法（ワーカビリティー判定法）の概念を示したもの である ${ }^{2)}$ この方法は、材料性質の把握と解析手法という 2 本の柱 を軸とするものであり、実大施工実験に比心゙、時間、費用等が節約 できるため、国際的にも認められた。現在、表 1 に示寸ように、流 動シミュレーション手法は幾つか提案されているが、解析に用いら れた構成モデルは、ビンガムモデルまたはその改良型である。

フレッシュコンクリートは、水と固体粒子によって構成される不

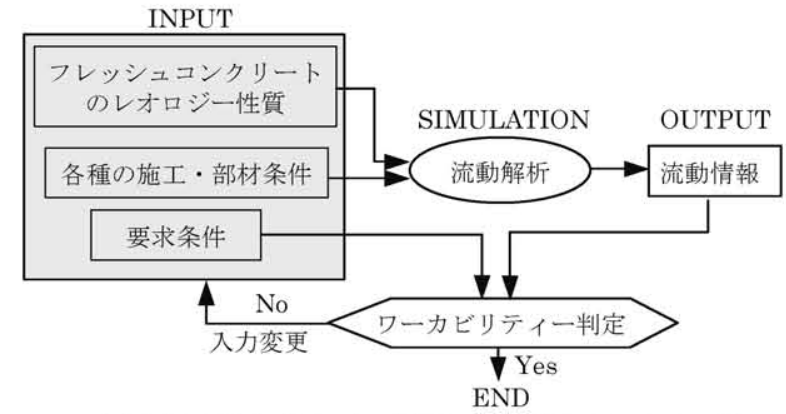

図 2 施工設計（ワーカビリティー判定）のコンセブト
* 山口大学大学院理工学研究科情報・デザイン工学系専攻 准教授 ·博士 (工学)

** 山口大学大学院理工学研究科情報・デザイン工学系専攻 大学院生・修士(工学)
Assoc. Prof., Dept. of Information and Design Engineering, Graduate School of Science and Engineering, Yamaguchi University, Dr. Eng.

Graduate Student, Dept. of Information and Design Engineering, Graduate School of Science and Engineering, Yamaguchi University, M. Eng. 
表 1 提案されたフレッシュコンクリートの流動解析手法

\begin{tabular}{|c|c|c|c|}
\hline 手法 & 材料モデル & 解析モデル & 出典 \\
\hline $\begin{array}{l}\text { 粘塑性有限要素法 } \\
\text { (VFEM) }\end{array}$ & \multirow{7}{*}{$\begin{array}{l}\text { 連続体モデル } \\
(\text { 単相モデル) }\end{array}$} & \multirow{2}{*}{ 複合モデル } & 森ら ${ }^{3)}$ \\
\hline $\begin{array}{l}\text { 粘塑性空間要素法 } \\
\text { (VDSEM) }\end{array}$ & & & 谷川ら ${ }^{4)}$ \\
\hline $\begin{array}{l}\text { フリーメッシュ法 } \\
\text { (SPH 法、MPS 法、FMM } \\
\text { 法) }\end{array}$ & & \multirow{4}{*}{$\begin{array}{l}\text { bi-viscosity } \\
\text { モデル }\end{array}$} & 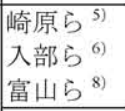 \\
\hline MAC 法 & & & 山田 $5^{7)}$ \\
\hline オイラー型有限要素法 & & & 富山ら 91 \\
\hline 剛塑性有限要素法 & & & 山田 $5^{10)}$ \\
\hline $\begin{array}{l}\text { オイラー・ラグランジェ } \\
\text { 複合型有限要素法 }\end{array}$ & & $\begin{array}{l}\text { チクソトロピ } \\
\text { 一型ビンガム } \\
\text { モデル }\end{array}$ & Roussel $^{11)}$ \\
\hline \multirow{2}{*}{$\begin{array}{l}\text { 粘塑性サスペンション } \\
\text { 要素法(VSEM) }\end{array}$} & \multirow{2}{*}{\begin{tabular}{|c|}
2 相モデル \\
(モルタルと粗 \\
骨材 $)$
\end{tabular}} & 複合モデル & 森ら ${ }^{12)}$ \\
\hline & & $\begin{array}{l}\text { ひずみ依存型 } \\
\text { モデル }\end{array}$ & 三島ら ${ }^{13)}$ \\
\hline 個別要素法(DEM) & 離散体モデル & ビンガムモデル & Chu $5^{14)}$ \\
\hline
\end{tabular}

均質で不安定な複合材料である。固体粒子の粒径は数 $\mu \mathrm{m}$ から数十 $\mathrm{mm}$ までの広範囲に及んでいる。粒子の凝集・分散および粒子間の摩擦・ 接触・衝突などによって、フレッシュコンクリートの変形・流動挙動 は、チキソトロピー特性、圧力依存性およびダイラタンシー特性など を示し、非常に複雑である。また、管内圧送に耐えるような液体に近 いものから、ローラーコンパクテッドコンクリートのような硬練りの ものまで、性質の相違が著しい。ビンガムモデルは、本来、粘性流体 に適用するモデルであるため、硬練りコンクリートの適用に無理が生 じる。高流動コンクリートの場合でも、フレッシュコンクリートの変 形抵抗性の圧力依存性 ${ }^{15)}$ 、ひず依存性 ${ }^{13)}$ 、非線型特性 ${ }^{16,17}$ および チキソトロピー ${ }^{18)}$ などが表現できない。また、ビンガムモデルの最大 の特徴として、せん断応力が降伏值を超えるまで、せん断ひずみ速度 はゼロとされている。つまり、降伏值より小さい応力を加えれば、変 形が生じない。しかし、実際に、小さいせん断応力を加えても、変形 が発生する ${ }^{199}$ 。フレッシュコンクリートのレオロジ一的性質を実験的 に考察して、モデル化する試み ${ }^{14,15)}$ があったものの、レオロジ一的性 質を的確に把握し、広範囲のコンクリートの変形・流動挙動を的確に 表すモデルが構築されるには至っていない。

二重円筒型回転粘度計、回転翼型粘度計および球引上げ粘度計な どの既存のレオロジ一試験方法のほとんどは、従来均質な液体を対 象に開発されたものであり、せん断ひずみ速度の増減に伴うせん断 応力の変化を観測するひずみ速度制御試験法である。つまり、強制 変形下のせん断抵抗を測定するものである。これらの試験法で得ら れた実験結果に基づいて提案されたモデルは、せん断抵抗モデルで あると考えられる。

しかし、コンクリートの圧送と打込み時の流動は、自重や圧力に よる自由変形である。また、圧送閉塞や障害物流動閉塞は、低速流 動を経て停止に至る現象である。コンクリートの施工設計の最も大 きい関心事が、その充填性を確実に実現することにあるため、自重 や圧力による流動およびポンプ配管内や鉄筋間における流動閉塞の 予測は極めて重要である。そこで、応力制御試験法によって、フレ ッシュコンクリートの小変形・低速変形から高速流動までのレオロ ジ一的性質を定量的に解明し、それらの性質を完全に反映するレオ ロジーモデル化を構築することは重要な課題である。
表 2 コンクリートの調合表

\begin{tabular}{c||c|c|c|c|c|c|c|c|c|c|c}
\hline \multirow{2}{*}{ Series } & \multirow{2}{*}{$\begin{array}{l}W / C \\
(\%)\end{array}$} & \multirow{2}{*}{$\begin{array}{c}D_{\max } \\
(\mathrm{mm})\end{array}$} & $\begin{array}{c}S / a \\
(\%)\end{array}$ & \multicolumn{4}{|c|}{ 質量 $\left(\mathrm{kg} / \mathrm{m}^{3}\right)$} & \multicolumn{3}{|c|}{ ユンシステンシー } \\
\cline { 6 - 12 } & & & & $C$ & $S$ & $G$ & $\begin{array}{c}S p \\
(C \times \%)\end{array}$ & $\begin{array}{c}S l . \\
(\mathrm{cm})\end{array}$ & $\begin{array}{c}S f . \\
(\mathrm{mm})\end{array}$ & $\begin{array}{c}T_{50} \\
(\mathrm{~s})\end{array}$ \\
\hline \hline $\mathrm{C} 1$ & 50 & 20 & 43.0 & 180 & 360 & 695 & 1047 & 1.25 & - & 595 & 1.71 \\
\hline $\mathrm{C} 2$ & 50 & 20 & 45.2 & 175 & 350 & 739 & 1020 & 1.00 & 22.5 & - & - \\
\hline $\mathrm{C} 3$ & 50 & 9.5 & 42.9 & 175 & 350 & 700 & 1060 & 1.50 & 22.5 & - & - \\
\hline $\mathrm{C} 4$ & 50 & 20 & 40.0 & 175 & 350 & 657 & 1119 & 1.50 & - & 603 & 3.65 \\
\hline $\mathrm{C} 5$ & 50 & 20 & 41.1 & 170 & 340 & 674 & 1100 & 1.00 & 14.0 & - & - \\
\hline
\end{tabular}

[注] $W / C$ : 水セメント比、 $S / a$ : 細骨材率、 $D_{\max }$ : 粗骨材の最大寸法、 $W, C, S, G, S_{p}$ : それぞれ水、セメント、海砂、砕石、高性能 $\mathrm{AE}$ 減 水剤、Sl. : スランプ、 $T_{50}: 50 \mathrm{~cm}$ フロー時間、 $S f .:$ スランプフロー

表 3 モルタルの調合表

\begin{tabular}{l||c|c|c|c|c|c|c|c}
\hline Series & M1 & M2 & M3 & M4 & M5 & M6 & M7 & M8 \\
\hline \hline W/C (\%) & 40 & 45 & 50 & 40 & 45 & 50 & 50 & 50 \\
\hline S/C & 1.50 & 1.50 & 1.50 & 1.80 & 1.80 & 1.80 & 1.80 & 1.80 \\
\hline$d_{\max }(\mathrm{mm})$ & \multicolumn{8}{|c|}{5} \\
\hline
\end{tabular}

[注] $S / C$ : 砂一セメント質量比、 $d_{\max }$ ：砂の最大寸法

表 4 セメントペーストの調合表

\begin{tabular}{l||c|c|c|c}
\multicolumn{7}{c}{ 表 4 セメントペーストの調合表 } \\
\hline Series & CP1 & CP2 & CP3 & CP4 \\
\hline \hline W/C (\%) & 33 & 36 & 39 & 30 \\
\hline
\end{tabular}

表 5 骨材の物理性質

\begin{tabular}{c||c|c|c|c|c|c|c}
\hline & 種類 & $\begin{array}{c}\text { 最大寸法 } \\
(\mathrm{mm})\end{array}$ & $\begin{array}{c}\text { 実積 } \\
\text { 率 }(\%)\end{array}$ & $\begin{array}{c}\text { 粗粒 } \\
\text { 率 }\end{array}$ & $\begin{array}{c}\text { 表乾密度 } \\
\left(\mathrm{g} / \mathrm{cm}^{3}\right)\end{array}$ & $\begin{array}{c}\text { 吸水率 } \\
(\%)\end{array}$ & $\begin{array}{c}\text { 単位容積質量 } \\
\left(\mathrm{kg} / \mathrm{m}^{3}\right)\end{array}$ \\
\hline \hline 粗骨材 & 砕石 & 20 & 59.4 & - & 2.73 & 0.39 & 1620 \\
\hline 細骨材 & 海砂 & 5 & - & 1.79 & 2.62 & 0.75 & - \\
\hline
\end{tabular}

筆者らは、この背景を踏まえて、応力制御法によってフレッシュ コンクリートの小変形・低速変形際の挙動について考察してきた ${ }^{20)}$ 。 本研究では、まず、応力制御試験法を用いて、フレッシュセメン 卜系材料の変形挙動に及ぼす試料の流動性、垂直圧力、荷重速度、 骨材の最大寸法、固体粒子の体積濃度および荷重持続時間の影響に ついて詳細に調べる。次に、実験結果に基づいて、フレッシュコン クリートのせん断変形モデルを提案し、各要因がモデルのパラメー タに与える影響をまとめる。

\section{2. 実験概要}

\section{1 試料の調合}

本研究の実験に用いた調合を表 2〜4 に示す。普通ポルトランドセ メント、海砂、砕石および標準型高性能 $\mathrm{AE}$ 減水剤を用いた。骨材 の物理性質を表 5 に示寸。コンクリート試料 C 3 に用いた砕石は、 表 5 に示す砕石を開き目が $9.5 \mathrm{~mm}$ の節でふるったものである。また、 モルタル試料 M7 と M 8 に用いた砂は、それぞれ図 5 に示す海砂を 開き目が $1.18 \mathrm{~mm}$ と $2.36 \mathrm{~mm}$ の篩でふるったものである。

\section{2 実験装置}

図 3 に示す小型せん断ボックス試験機を用いた。せん断ボックス に充填した試料のサイズは、幅 $30 \mathrm{~cm} \times$ 奥行き $20 \mathrm{~cm} \times$ 深さ $20 \mathrm{~cm}$ で ある。また、試料とせん断ボックスの内側壁の間に生じる摩擦・粘 性抵抗を低減するために、ボックスの側壁は、図 4 に示すように、 U 字型アルミ部材をリニアベアリングによって接合した構造になっ ている。したがって、試料を直接にせん断ボックスに充填すること ができず、ビニル袋を詰めてボックスに挿入した。 


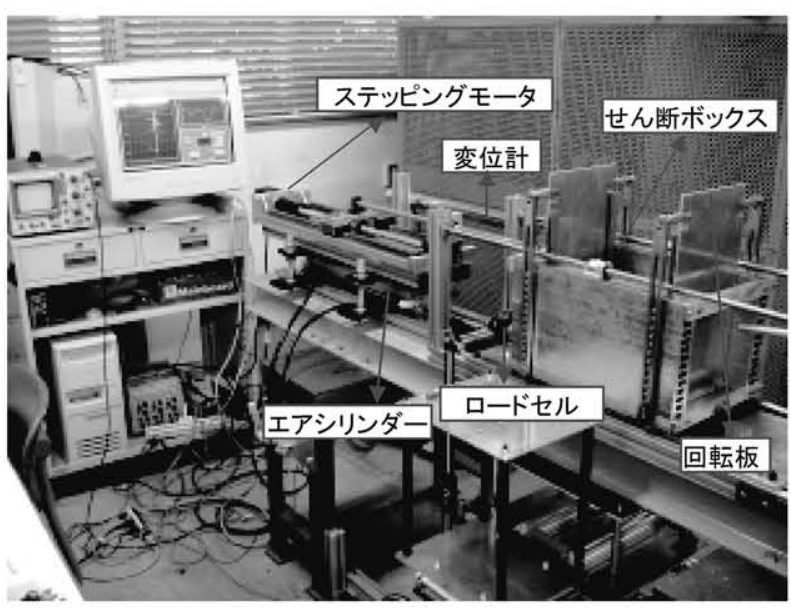

図 3 小型せん断ボックス試験機(応力制御とひずみ制御両用型)

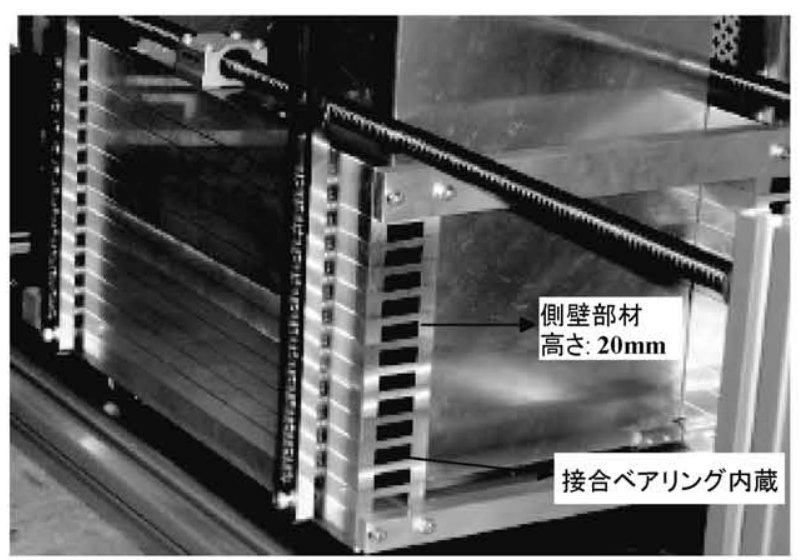

図 4 せん断ボックスの側壁の構造

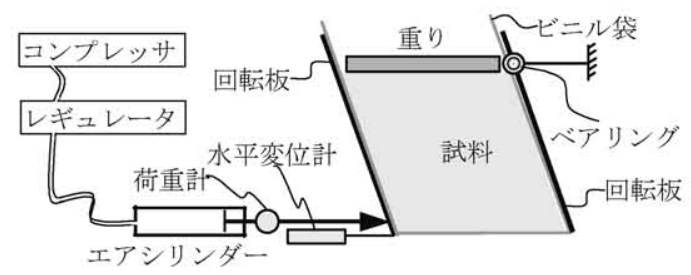

図 5 応力制御試験法の原理図

この試験機は、応力制御とひずみ制御の両用型のものである。ひ ずみ制御法の場合には、ボックスの底部を固定して、ステッピングモ 一夕によってボックスの頂部を駆動して、頂部の水平変位を測定する。 応力制御法で試験する場合、ボックスの頂部を固定して、エアシリ ンダーでせん断ボックスの底部にせん断荷重を加え、底面の水平変位 を変位計で測定する (図 5 の原理図を参照)。加えたせん断荷重を口 ードセルで測定する。コンプレッサとエアシリンダーの間に存在する レギュレータで空気圧を制御することによって、エアシリンダーの駆 動力をゼロから $1 \mathrm{kN}$ まで増大させる。また、試料の上面に載せる重り を変えて垂直圧力を調整する。

載荷速度および垂直圧力のレベルを変えて、高粘性校正材料によ って実験装置の抵抗を予め測定した ${ }^{20}$ 。装置抵抗を測定した際に用 いたビニル袋は、コンクリート実験に使ったものと同じである。高
粘性校正材料は、コーンシッロプと石灰石微粉末で作られたニュー トン体であり、その粘度は平行板粘度計で測定した。

\section{3 実験方法}

練り混ぜ直後の試料を厚みが $0.03 \mathrm{~mm}$ のビニル袋に詰めた後にせ ん断ボックスに入れ、垂直圧力を加えるための板状重りを試料の上 に載せた。実験結果の図に注記する場合を除き、試料の高さは $18 \mathrm{~cm}$ とした。次に、載荷速度を設定して、エアシリンダーの駆動で、せ ん断ボックスの底部に水平荷重を加えた。同時に、加えた水平力と

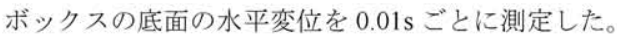

測定した水平力から装置抵抗を引いて、試料のせん断応力を計算 した。また、測定した時間ごとの水平変位からせん断ひずみとせん 断ひずみ速度を求めた。垂直圧力は、載せた重りの重量を試料の面 積で除すことによって算定した。

\section{3. せん断変形特性およびモデル化}

\section{1 応力制御法で測定した流動曲線}

図 6 に、応力制御法で得られたセメントペースト、フレッシュモル タルおよびフレッシュコンクリートのせん断ひずみとせん断応力の 関係を示す。せん断ひずみが 0.9 以下の小変形領域において、試料の 種類に拘わらず、せん断ひずみは、せん断応力の増大に伴って大きく なったが、試料の流動性および応カレベルによって増大傾向が異なる ことがわかった。各試料のせん断ひずみは、応力の増大に伴って、最 初に急激に増大した（グラフが右下に凸）が、ある值に達すると、緩 やかに増大寸る（グラフが左上に凸）傾向が見られた。ここに、最初 の段階を高速増大段階と、次の段階を緩慢増大段階と呼ぶことにする。 また、同図に示寸ように、試料の流動性が高いほど、高速増大段階の 限界ひずみが大きいが、限界せん断応力は小さかった。

図 6(a)に示すように、セメントペーストの場合には、せん断ひず みは、緩慢に増大した後、再度急激に大きくなり、せん断応力が減 小する傾向が見られた。この段階を急速増大段階と称することにす る。同図に示すように、セメントペーストの流動性が高いほど、2 度目に増大し始める時点のひずみと応力は共に小さかった。用いた 小型せん断ボックスで測定できる最大のせん断ひずみは 1.0 に限ら れているため、今回の実験ではモルタルとコンクリート試料のひず みの急速増大段階の挙動を観察できなかった(図 6(b), (c)を参照)。

図 7 に、応力制御法で得られたセメントペースト、フレッシュモ ルタルおよびフレッシュコンクリートのせん断ひずみ速度とせん断 応力の関係を示す。これらの図に示すように、モルタルとコンクリ 一トの試料のせん断ひずみ速度はせん断応力の増大に伴って、最初 に増大するが、ピーク值を超えると、逆に減小する傾向が見られた (図 7(b), (c)を参照)。一方、図 7(a)より、セメントペーストのせん 断ひずみ速度は、増大 $\rightarrow$ 減小 $\rightarrow$ 急速増大という 3 段階で変化するこ とが観察された。また、図 7(a)に示すように、試料の流動性が高い ほど、ピークせん断速度とそれに対応するせん断応力が小さく、2 度目に増大し始めるひずみ速度は大きかったが、それに対応するせ ん断応力は小さかった。

\section{2 せん断変形モデルの提案}

本研究では、応力制御法によって測定したせん断ひずみ/速度は、 フレッシュコンクリートの外力に対する自由変形応答である。した がって、この実験結果に基づいて下記に提案したモデルは、応力作 


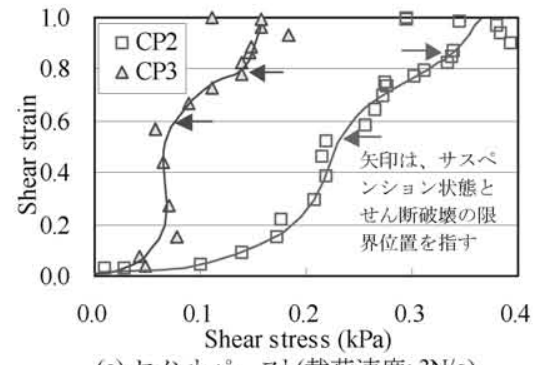

(a) セメントペースト(載荷速度: $3 \mathrm{~N} / \mathrm{s}$ )

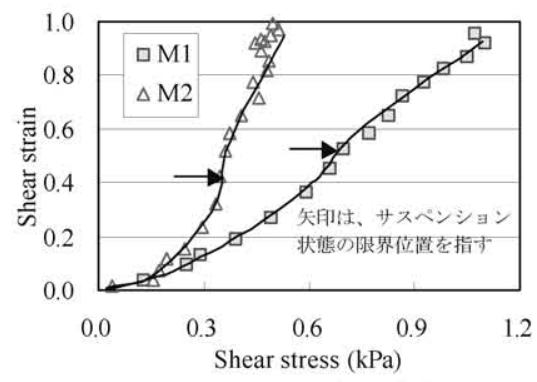

(b) フレッシュモルタル(載荷速度: $6 \mathrm{~N} / \mathrm{s}$ )

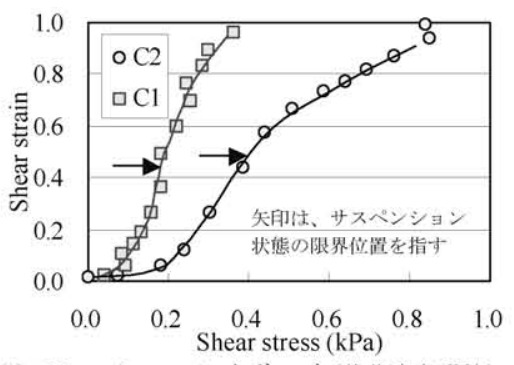

(c) フレッシュコンクリート(載荷速度: $6 \mathrm{~N} / \mathrm{s})$

図 6 セメント系材料のフレッシュ時のせん断ひずみとせん断応力の関倸(垂直圧力 : $0 \mathrm{~Pa}$ )

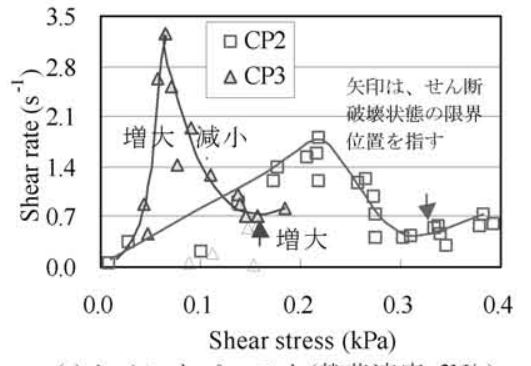

(a) セメントペースト(載荷速度: $3 \mathrm{~N} / \mathrm{s}$ )

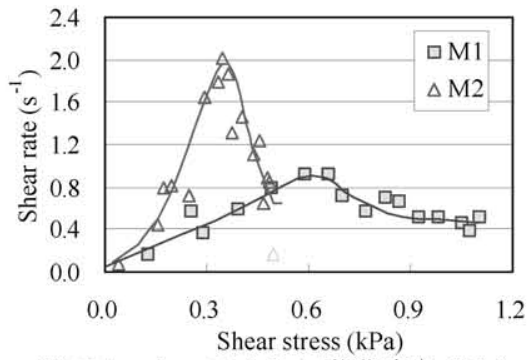

(b) フレッシュモルタル(載荷速度: $6 \mathrm{~N} / \mathrm{s}$ )

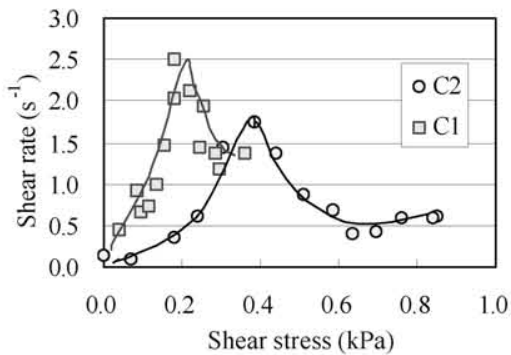

(c) フレッシュコンクリート(載荷速度: $6 \mathrm{~N} / \mathrm{s}$ )

図 7 セメント系材料のフレッシュ時のせん断ひずみ速度とせん断応力の関倸(垂直圧力 : $0 \mathrm{~Pa}$ )

用下のせん断変形モデルであると考えている。

前述のように、応力の増大に伴って、セメントペーストのせん断ひ ずみは、高速増大 $\rightarrow$ 緩慢増大 $\rightarrow$ 急速増大という順で変化し、せん断ひず み速度は増大 一減小 急速増大する特徵が現れた。しかし、せん断ボッ クスの水平せん断変位に制限（18cm）があるため、測定できる最大せ ん断ひずみは 1.0 (試料厚さ: $18 \mathrm{~cm}$ の場合)である。モルタルとコンクリ 一ト試料の急速増大段階におけるせん断ひずみ/速度とせん断応力の関 係曲線が測定できなかった。後述のように、これは、大きい粒子を含む 試料は、急速増加段階に至るまで、大きな変形 (せん断ひずみ) が必要 であるためであると考えている。上記の実験結果に基づいて、フレッシ ユコンクリートのせん断変形モデルを図 8 に示すように提案した。

フレッシュ状態のセメント系材料は、水と粒子で構成されているた め、そのレオロジ一的性質は粒子のインターロキングとダイラタンシ 一に依存する。試料の応力状態は、せん断応力の増大に伴って、粒子

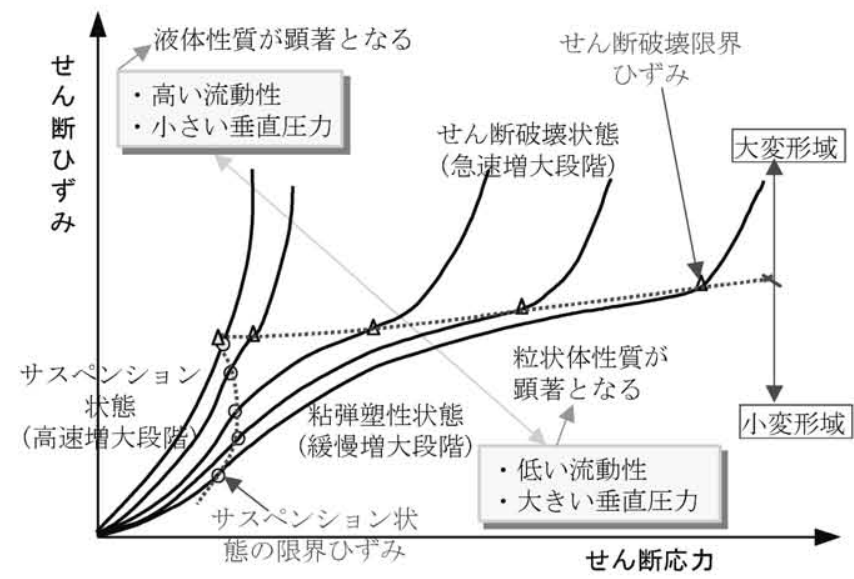

(a) せん断ひずみ一せん断応力関係
の接触程度とダイラタンシーによって、サスペンション状態、粘弹塑 性状態およびせん断破壞状態の順に移行する。サスペンション状態の 限界応力とひずみおよびせん断破壊限界応力とひずみによって試料 の応力状態を区別する。前述した高速増大段階、緩慢増大段階および 急速増大段階における変形挙動は、それぞれサスペンション状態、粘 弹塑性状態およびせん断破壊状態に対応寸るものであると思われる。

フレッシュコンクリートがせん断力を受ける初期では、粒子の噛 み合いまたはインターロキングの程度が小さいため、高濃度サスペ ンションとみなすことができ、流体の特徴が顕著である。せん断応 力の増大に伴って、ひずみが大幅に増大して、せん断ひずみ速度が 大きくなる（図 8(a), (b)に示すサスペンション状態)。

粒状体の粒子挙動の可視化実験の結果によれば、粒子が受けた外 力に対抗するため、滑動抵抗が大きい位置に移動して、平均粒子接 点角は増大寸るが、ある限界を超えると、逆に変形と共に減小して

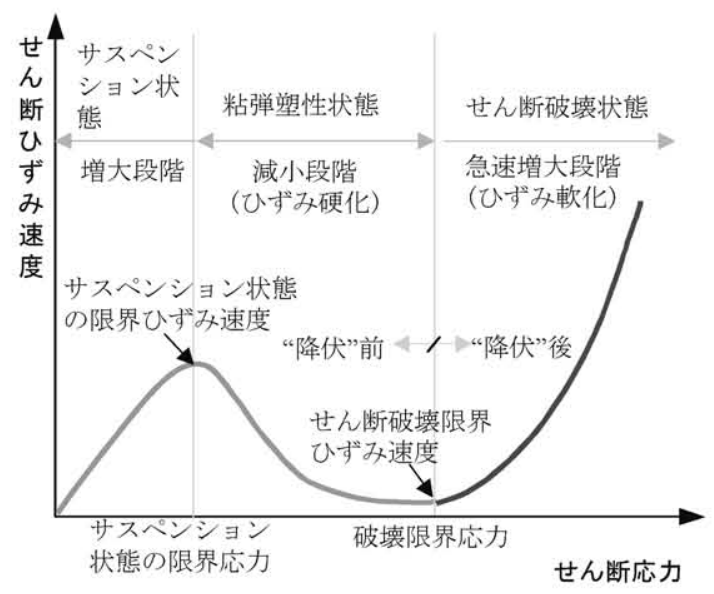

(b) せん断ひずみ速度一せん断応力関係

図 8 フレッシュコンクリートのせん断変形モデル 
いく 21-22)。これによって、外力を受けたフレッシュコンクリート中 の粒子は、まず外力によって移動して、ついに外力による粒子間力 に対抗できる位置に至り、粒子の噌み合いの程度は大きくなる。粒 子の謎み合いの程度が大きくなると、内部摩擦抵抗が大きくなり、 ダイラタンシーが発生し、試料の変形抵抗が大きくなる(ひずみ硬 化と呼ばれる)。マクロな現象として、ダイラタンシーの発生に伴っ て、せん断方向に直交する方向に垂直ひずみが生じる。したがって、 せん断応力の増大に伴って、せん断ひずみは大きくなるが、その増 大量は小さくなる。つまり、試料の自由変形速度(せん断ひずみ速度) は小さくなる。この段階では、試料が粘弾塑性状態にあると考えら れる(図 8(a)の緩慢増大段階, 図 8(b)の減小段階)。

しかし、せん断応力をさらに増大すると、一部の粒子は、滑動抵抗の 限界を超える粒子間力を受けるため、粒子間力に対抗できる位置に至ら

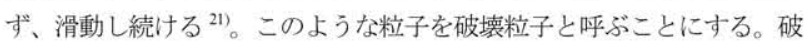
壊粒子が生じると、試料はせん断破壊状態に入り、その恋形抵抗は変形 と共に減小していく(ひずみ軟化と呼ばれる)。マクロな現象として、試 料のせん断ひずみは大幅に増大し、せん断ひずみ速度は応力と共に急激 に増大寸る(図 8(a),(b)の急速増大段階)。セメントペーストの 2 度目のせ ん断ひずみ速度の増大は、せん断破壊状態の挙動であると考えられる。 本研究では、セメントペーストのみのせん断破壊状態におけるひ ずみの急速増大現象を観察できた。現在のせん断実験装置で、フレ ッシュコンクリートのせん断破壊状態の挙動を直接に観察できない が、土などの粘弾塑性材料の特性を考虑すると、フレッシュコンク リートは、粘弹塑性材料(含水粒状体) として、せん断破壊状態が存 在し、破壞状態においてはせん断ひずみ速度が図 8(b)に示すように 応力と共に増大寸ると考えることができる。

フレッシュコンクリートは、せん断破壊状態に至る直前に、粘弾 塑性状態にあり、そのせん断ひずみ速度はかなり小さいため、二重
円筒などによるレオロジー試験では測定されにくく、マクロな現象 としての流動は観察されない。したがって、“降伏”前の状態は、せ ん断破壊状態までの状態に相当すると考えられる。

3.1 節に述べた実験結果より、セメント系材料の流動性が高いほど、 サスペンション状態の限界応力、せん断破壊限界応力およびせん断破壊 限界ひずみは小さいが、サスペンション状態の限界ひずみは大きいこと が認められた。また、試料の流動性が高いほど、サスペンション状態の 限界せん断速度が大きく、限界せん断応力が小さいことがわかった。

試料のせん断ひずみ一せん断応力関係曲線の流動性による変化傾 向を図 8(a)に示す。流動性の低下に伴って、フレッシュコンクリー 卜の粒状体特性は顕著となり、粘弾塑性状態は長く持続する。提案 したモデルは、硬練りから高流動までの広範囲のコンクリートのせ ん断変形特徵を表すことができる。

\section{4. せん断変形特性に対する各要因の影響 \\ 4. 1 垂直圧力の影響}

図 9 は、垂直圧力を変えて応力制御法で測定したせん断ひずみと せん断応力の関係曲線を示したものである。同図に示寸ように、同 じせん断応力に対して、垂直圧力の増大に伴って、せん断ひずみが 小さくなる傾向が見られた。垂直圧力の増大に伴って、サスペンシ ヨン状態の限界ひずみが小さくなったが、限界応力は大きくなった。 サスペンション状態の限界ひずみの減小は、垂直圧力の増大に伴っ て、粒子の噌み合いが急速に増大し、サスペンション状態が速やか に終了したためであると推測している。

図 9(a)では、セメントペーストCP4 のせん断破壊状態における自由 変形举動が見られた。せん断破壊状態に至ると、せん断応力はあまり増 えなくても、または減小しても、せん断ひずみは大幅に増大した。また、 せん断破壊限界応力と限界ひずみは、垂直圧力と共に大きくなることが

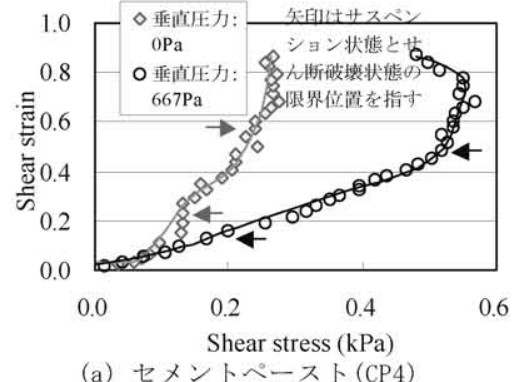

(a) セメントペースト (CP4)

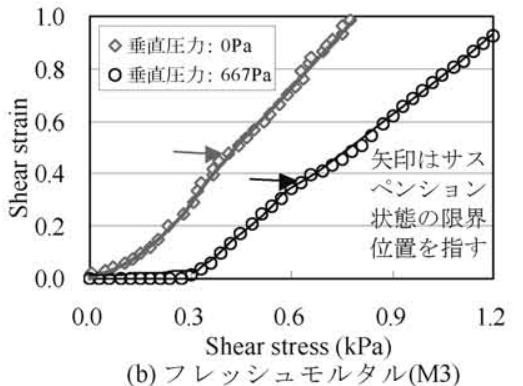

(b) フレッシュモルタル(M3)

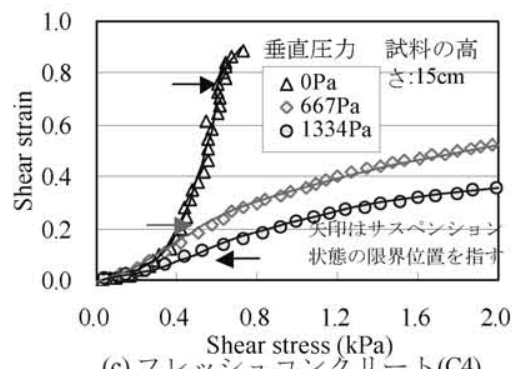

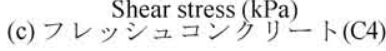

図 9 セメント系材料のフレッシュ時のせん断ひずみとせん断応力の関係に及ぼす垂直圧力の影響(載荷速度: $5 \mathrm{~N} / \mathrm{s}$ )

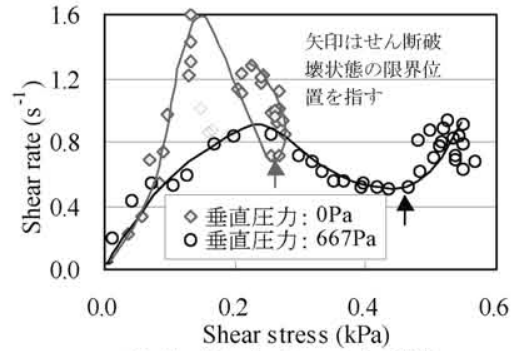

(a) セメントペースト(CP4)

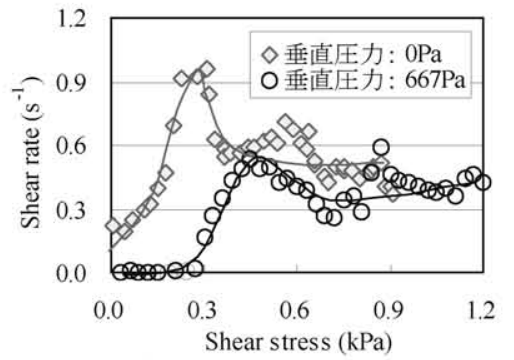

(b) フレッシュモルタル(M3)

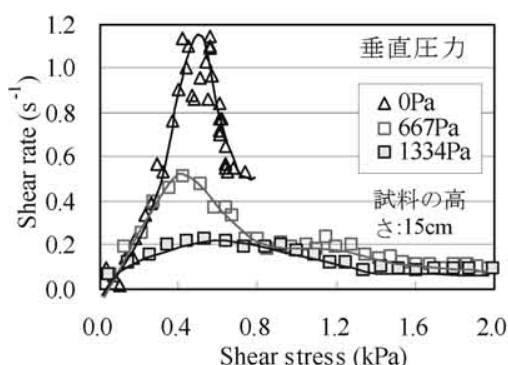

(c) フレッシュコンクリート(C4)

図 10 セメント系材料のフレッシュ時のせん断ひずみ速度とせん断応力の関係に及ぼす垂直圧力の影響(載荷速度: $5 \mathrm{~N} / \mathrm{s}$ ) 


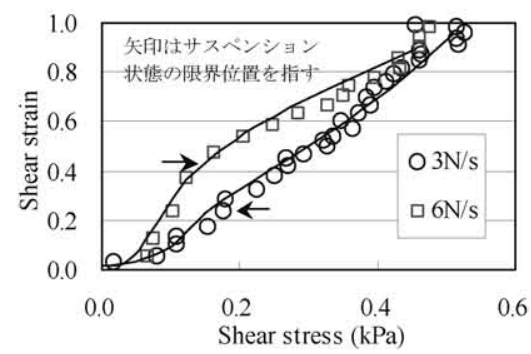

(a) セメントペースト (CP1)

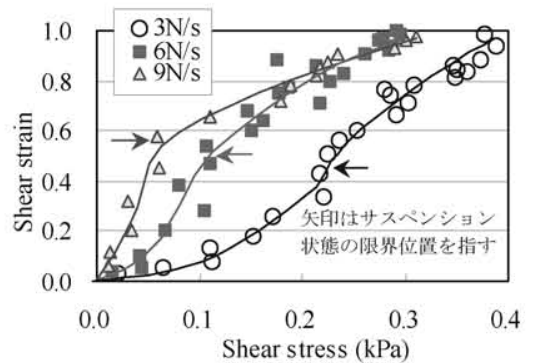

(b) フレッシュモルタル (M6)

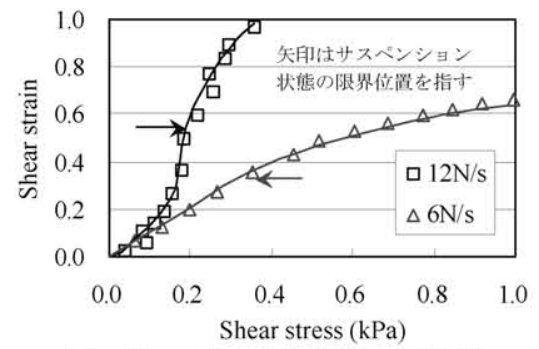

(c) フレッシュコンクリート (C 1)

図 11 各試料のせん断ひずみとせん断応力の関係に及ぼす載荷速度の影響(垂直圧力 : $0 \mathrm{~Pa}$ )

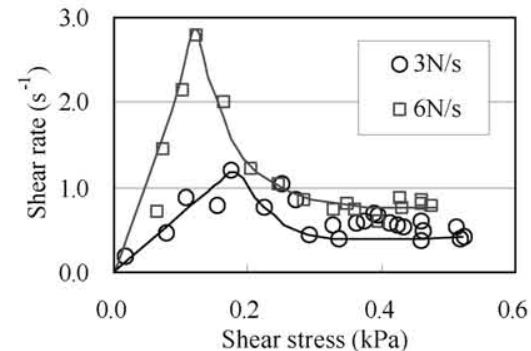

(a) セメントペースト (CP1)

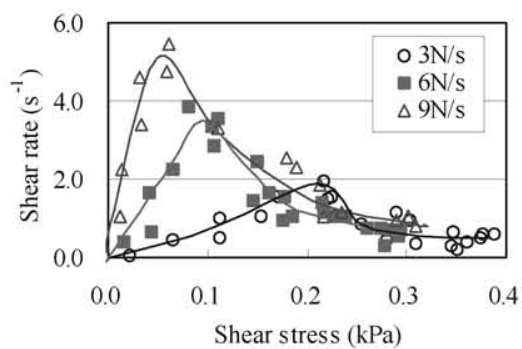

(b) フレッシュモルタル (M6)

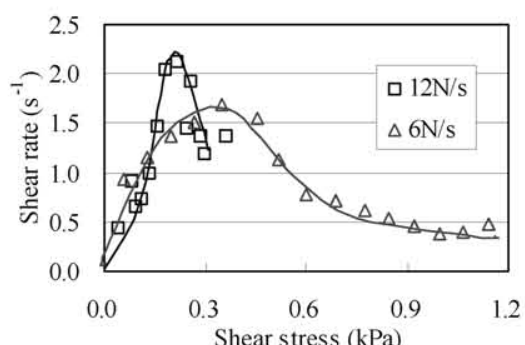

(c) フレッシュコンクリート (C 1)

図 12 各試料のせん断ひずみ速度とせん断応力の関係に及ぼす載荷速度の影響(垂直圧力 : $0 \mathrm{~Pa}$ )

わかった。これは、粒子の噛み合いが垂直圧力とともに増大し、内部摩 擦抵抗およびダイラタンシーによる抵抗が大きくなったためである。

図 10 に、せん断ひずみ速度一せん断応力関係に及ぼす垂直圧力の 影響を示す。同図によれば、垂直圧力の増大に伴って、せん断ひず み速度およびサスペンション状態の限界ひずみ速度が小さくなり、 サスペンション状態の限界応力が増大寸ることが認められた。なお、 図 10(a)に示すように、垂直圧力が小さいほど、試料 CP4 のせん断 破壊限界応力は小さく、限界ひずみ速度は大きくなった。試料 CP4 はせん断破壞状態に至ると、そのせん断ひずみ速度が、応力の増加 と共に急激に増大寸る傾向が見られた。

試料のせん断ひずみ一せん断応力関係曲線の垂直圧力による変化 傾向を図 8(a)k示す。垂直圧力の増大に伴って、フレッシュコンク リートの粒状体特性が顕著となり、粘弾塑性状態は長く持続する。

\section{2 載荷速度の影響}

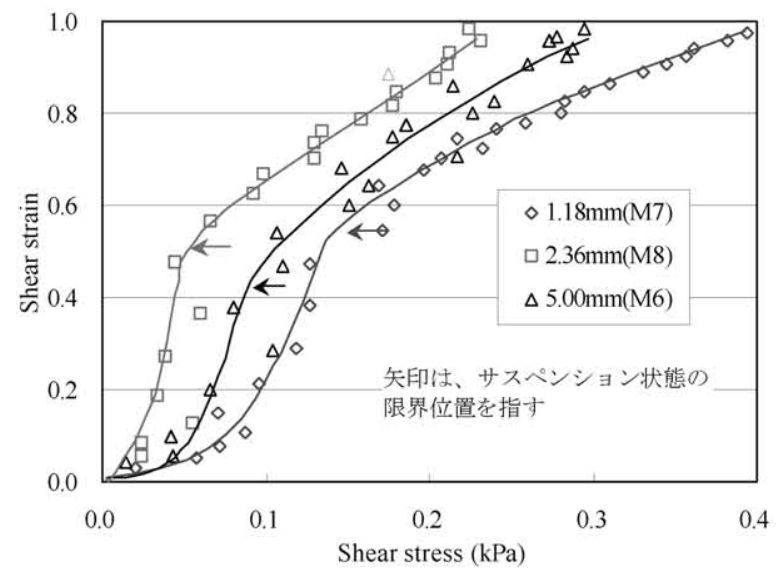

図 13 せん断ひずみとせん断応力の関係に及ぼす粒子最大寸法の 影響(載荷速度 : $6 \mathrm{~N} / \mathrm{s}$, 垂直圧力 : $0 \mathrm{~Pa}$ )
図 11 に、各試料のせん断ひずみとせん断応力の関係に及ぼす載荷 速度の影響を示す。同図を見ると、載荷速度が大きいほど、同じせ ん断応力によるせん断ひずみが大きく、サスペンション状態の限界 ひずみは大きくなったが、限界応力は小さくなる傾向が見られた。

また、図 12 に、各試料のせん断ひずみ速度とせん断応力の関係に 及ぼす載荷速度の影響を示す。同図によれば、載荷速度の増大に伴 って、サスペンション状態の限界ひずみ速度は大きくなったが、限 界せん断応力は小さくなることがわかった。

なお、図 12(a)に示すように、載荷速度が大きいほど、せん断ひず み速度の減小段階における最小せん断速度、つまり、せん断破壊限 界せん断ひずみ速度は大きいが、限界応力は小さかった。

\section{3 粒子の最大寸法の影響}

図 13 に、骨材粒子の最大寸法が異なる細骨材と粗骨材を用いたモ ルタル、コンクリートのせん断ひずみとせん断応力の関係を示す。

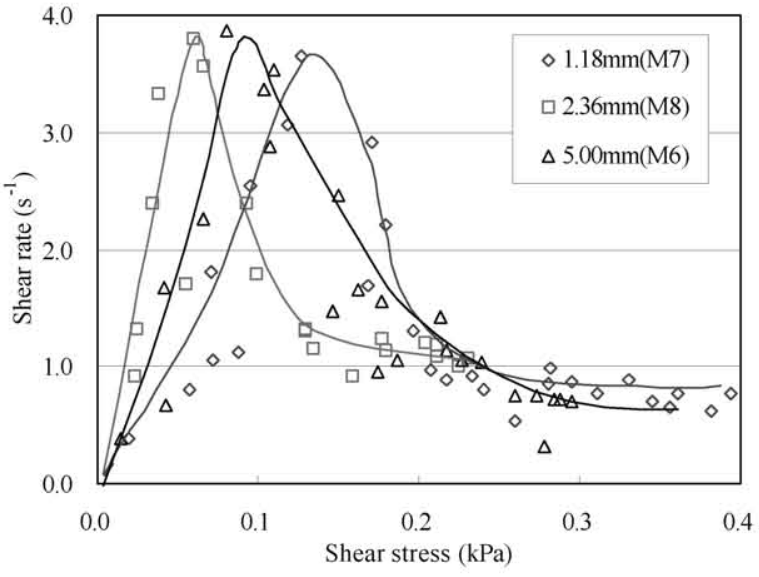

図 14 せん断ひずみ速度とせん断応力の関係に及ぼす粒子の 最大寸法の影響(載荷速度 : $6 \mathrm{~N} / \mathrm{s}$, 垂直圧力 : $0 \mathrm{~Pa}$ ) 


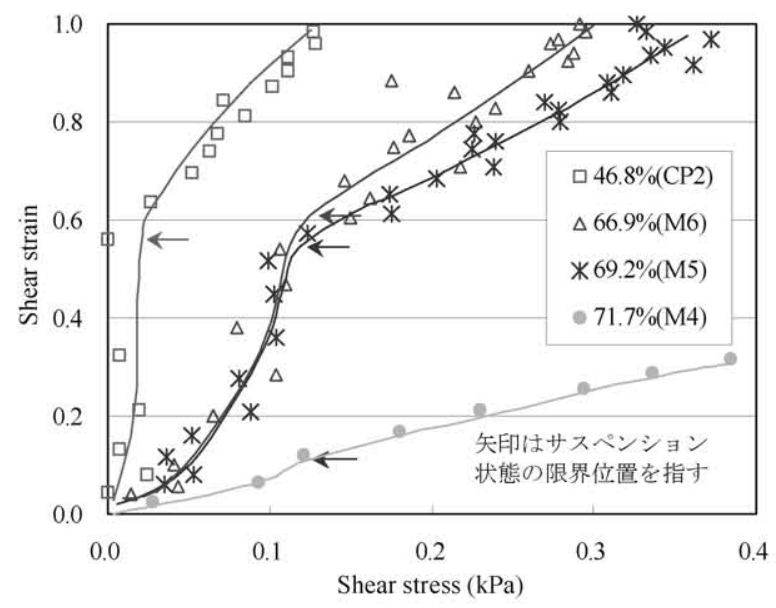

図 15 せん断ひずみとせん断応力の関係に及ぼす粒子体積濃度 の影響(載荷速度 : $6 \mathrm{~N} / \mathrm{s}$, 垂直圧力 : $0 \mathrm{~Pa}$ )

この図に示すように、粒子の最大寸法が大きいほど、サスペンショ ン状態の限界ひずみは小さい。しかし、サスペンション状態の限界 せん断応力に一定の傾向が見られなかった。これは試料の流動性が 支配的な影響を与えたためである。

また、図 14 は、せん断ひずみ速度とせん断応力の関係を示したもの である。粒子の最大寸法の増大しても、サスペンション状態の限界せん 断ひずみ速度および限界せん断応力に一定の傾向は見られなかった。こ れは、試料の粘性と粒状体性質が支配的な影響を与えたためである。例 えば、最大寸法が $5 \mathrm{~mm}$ の砂を使用した試料 M6 は、粘性が低いが、粒 状体特性が顕著であるため、せん断速度は必ずしも大きくはならない。

\section{4 粒子体積濃度の影響}

図 15 は、固体粒子体積濃度が異なるセメントペーストおよびモル夕 ルのせん断ひずみ一応力関係曲線を示したものである。同図に示すよう

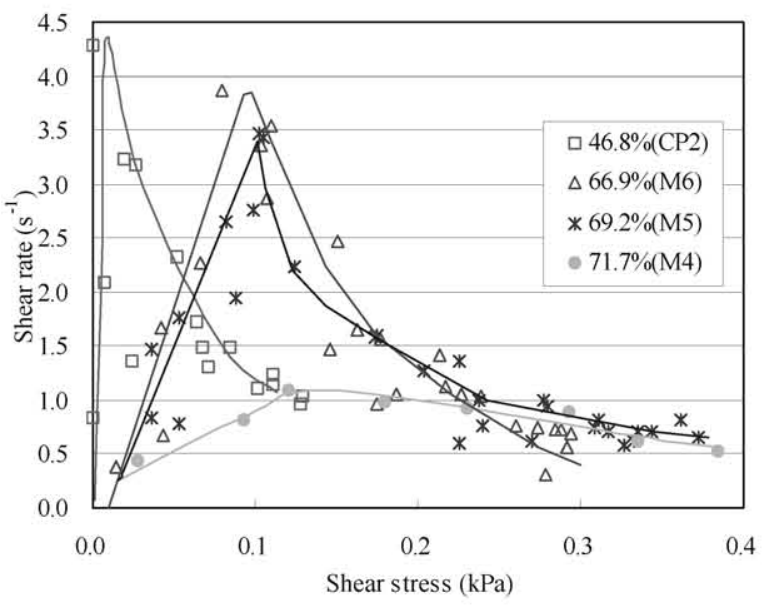

図 16 せん断ひずみ速度とせん断応力の関係に及ぼす粒子体積 濃度の影響(載荷速度 : $6 \mathrm{~N} / \mathrm{s}$, 垂直圧力 : $0 \mathrm{~Pa}$ )

に、同じせん断応力に対して、粒子体積濃度が小さいほど、せん断ひず みが大きい。また、粒子体積濃度の減小に伴って、サスペンション状態 の限界ひずみは大きくなったが、限界応力は減小寸る傾向が見られた。

図 16 に、粒子体積濃度が異なる試料のせん断ひずみ速度一応力曲 線を示す。同図によれば、試料の粒子体積濃度が大きいほど、サス ペンション状態の限界ひずみ速度は小さく、限界せん断応力は大き くなることが認められた。

\section{5 載荷持続時間の影響}

図 17 に、せん断応力と垂直圧力が一定である時におけるセメント 系材料のフレッシュ時のせん断変形の経時変化を示す。同図に示す ように、所定のせん断荷重と垂直圧力を加えると、試料のせん断ひ ずみは、高速増大段階および緩慢増大段階を経て大きくなった。ま た、せん断ひずみ速度は、最初に増大するが、ある值に達すると、

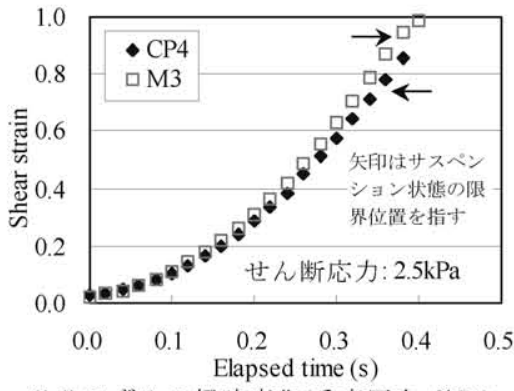

(1-1)ひずみの経時変化(垂直圧力: $0 \mathrm{kPa}$ )

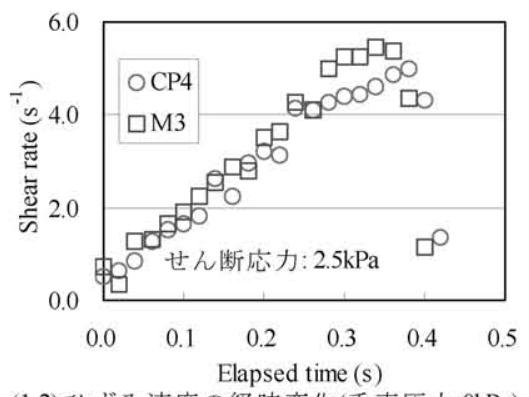

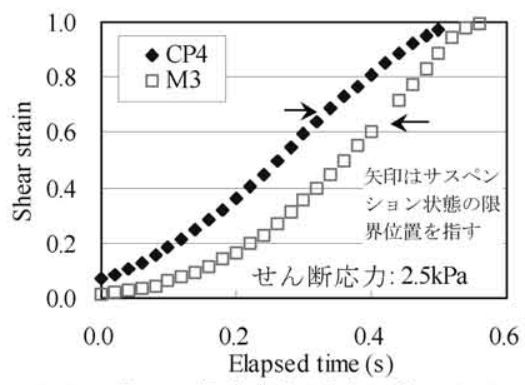

(2-1)ひずみの経時変化(垂直圧力: $1.3 \mathrm{kPa}$ )

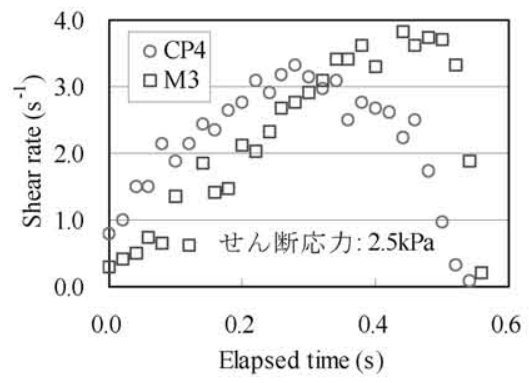

(2-2)ひずみ速度の経時変化(垂直压力:13kPa)

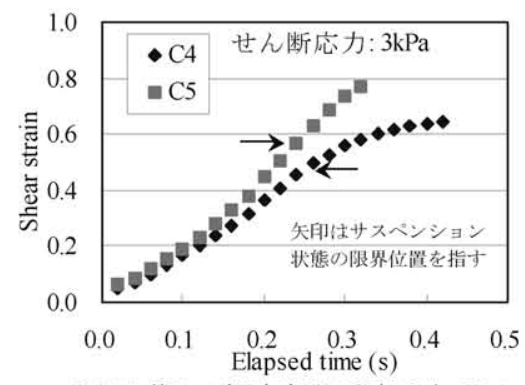

(3-1)ひずみの経時変化(垂直圧力: $0 \mathrm{~Pa}$ )

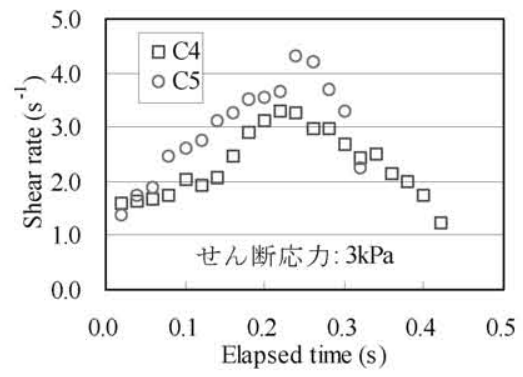

(3-2)ひずみ速度の経時変化(垂直圧力: $0 \mathrm{~Pa}$ )

図 17 セメント系材料のフレッシュ時のせん断変形の経時変化（試料の高さ: $15 \mathrm{~cm})$ 
表 6 サスペンション状態の限界応力、せん断ひずみおよび せん断ひずみ速度に及ぼす各種要因の影響

\begin{tabular}{l||c|c|c}
\hline & $\tau_{s}$ & $\gamma_{s}$ & $\dot{\gamma}_{s}$ \\
\hline \hline 流動性を増大 & 小 & 大 & 大 \\
\hline 垂直圧力を増大 & 大 & 小 & 小 \\
\hline 載荷速度を増大 & 小 & 大 & 大 \\
\hline 粒子の最大寸法を増大 & 大 & 小 & - \\
\hline 粒子の体積濃度を増大 & 大 & 小 & 小
\end{tabular}

[注] $\tau_{s}$ : サスペンション限界応力、 $\gamma_{s}$ : サスペンション限界ひずみ、 $\dot{\gamma}_{s}:$ サスペンション限界ひずみ速度

減小していく傾向が見られた。各試料のせん断破壊状態を含めた各 応力状態の挙動を観察するために、せん断破壊限界応力より大きい せん断応力を加えた。本実験装置では、測定できる最大せん断ひず みが限られているため、破壞限界応力以上のせん断荷重を加えても、 せん断破壊段階の変形特性は観察できなかった。

上記の実験結果に基づいて、サスペンション状態の限界応力、限 界ひずみおよび限界ひずみ速度に及ぼす各要因の影響を表 6 にまと めて示す。せん断破壊状態の限界応力、ひずみおよびひずみ速度の 影響要因についての詳細な検討は今後の課題である。

\section{5. まとめ}

本研究では、小型せん断ボックス試験機を利用して、応力制御法 でフレッシュセメント系材料の外力に対する自由変形応答およびそ れに与える各種要因の影響について考察した。得られた結果に基づ いて、硬練りから高流動までの広範囲のフレッシュコンクリートの せん断変形特性を表現するモデルを図 8 に示すように提案した。得 られた知見は、以下のようにまとめられる。

1）フレッシュコンクリートの応力状態は、サスペンション状態、 粘弾塑性状態およびせん断破壊状態に分けられる。各状態にお ける外力下の挙動は、自由変形応答である。

2）粘弾塑性状態において、ダイラタンシーによる抵抗が外力と共 に増大寸るため、外力に対する応答としての自由変形は増大寸 るが、変形速度は減小寸る。

3）流動性、垂直圧力および粒子体積濃度の増加に伴って、フレッ シュコンクリートの粒状体特性は顕著になり、ダイラタンシー が発生しやすくなるため、サスペンション状態の限界ひずみと ひずみ速度は小さくなるが、サスペンション状態の限界応力お よびせん断破壊限界ひずみと限界応力は増大する。

4）載荷速度が大きいほど、せん断ひずみと速度は大きく、サスペンショ ン状態の限界ひずみと速度は大きくなるが、限界応力は小さくなる。 現在のせん断実験装置では、すべての試料のせん断破壞状態にお ける変形挙動が測定できなかった。今後、応力制御法で大変形状態 を測定できる装置を開発して、大変形時の挙動について考察し、各 種の限界応力、限界ひずみおよび限界ひずみ速度の影響要因を定量 的に調べる必要がある。また、理論解析を行い、せん断応力一せん 断ひずみ/速度の関係式を求める予定である。

\section{謝辞}

本研究を遂行するにあたり、装置の設計・試作に筑波大学大学院 システム情報工学研究科 飯高稳氏にご協力をいただきました。こ
こに、付記して謝意を表します。

参考文献

1) 日本建築学会 : 建築工事標準仕様書・同解説, JASS 5 鉄筋コンクリート 工事, pp.163-165, 1997.

2）谷川恭雄・森博䀦: コンクリートの「施工設計法」の確立をめざして, セ メント・コンクリート, No.501, pp.11-20, 1988.11.

3) 森博品・谷川恭雄: 粘塑性有限要素法によるフレッシュコンクリートの 流動解析, 日本建築学会構造系論文集, No.374, pp.1-9, 1987.4.

4) Tanigawa, Y., Mori, H., and Watanabe, K. : Flow simulation of fresh concrete by Viscoplastic Divided Space Element Method, Proc. of $33^{\text {rd }}$ Japan Congress on Materials Research, pp.227-233, 1990.3.

5) 崎原康平・伊良波繁雄ほか: SPH 法によるフレッシュコンクリートの流 動解析，コンクリート工学年次論文集, Vol.26, No.1, pp.1149-1154, 2004

6) 入部網清・伊良波繁雄ほか：MP S 法による粗骨材を考虑したフレッシ ュコンクリートの三次元流動解析, コンクリートエ学年次論文集, Vol.26, No.1, pp.1161-1166, 2004.

7) 山田義智・大城武・栘田佳寛 : フレッシュコンクリート流動解析への $\mathrm{M}$ A C 法の適用, コンクリート工学年次論文集, Vol.20, No.1, pp.131-136, 1998.

8) 富山潤・山田義智ほか: フリーメッシュによるフレッシュコンクリート の粘塑性流動解析, コンクリート工学年次論文集, Vol.24, No.1, pp.861-866, 2002.

9) 富山潤・山田義智ほか: オイラー型有限要素法によるフレッシュコンク リートの流動解析, コンクリート工学年次論文集, Vol.27, No.1, pp. 1039-1044, 2005.

10) 山田義智・桃原睦・大城武 : 有限要素法によるフレッシュコンクリート の粘塑性流動解析, コンクリート工学年次論文集, Vol.23, No.2, pp.253-258, 2001.

11) Roussel, N. : A thixotropy model for fresh fluid concrete: theory, validation and application, Cement and Concrete Research, Vol.36, pp.1797-1806, 2006.

12）森博喔・渡辺健治・梅本宗宏・谷川恭雄: 二相モデルを用いたフレッシ ココンクリートの流動解析手法, 日本建築学会構造系論文集, No.427, pp.11-21, 1991.9.

13) Chu, H., Machida, A., and Suzuki, N.: Experimental investigation and DEM simulation of filling capacity of fresh concrete, Trans. of the Japan Concrete Institute, Vol.16, pp.9-14, 1996.

14）森博嗣・田中政史・谷川恭雄 : フレッシュコンクリートのせん断変形性 質に関寸る実験的研究, 日本建築学会構造系論文報告集, No.421, pp.1-10, 1991.3.

15) 三島直生: ダイラタンシーおよび凝集を考慮した高濃度サスペンション のレオロジーモデルの構筑とその定量化に関する研究, 名古屋大学博 士論文, pp. 98-100, 2001.3.

16) Wallevik, J. E.: Rheology of particle suspensions, Ph. D Thesis of Norwegian University of Science and Technology, pp.11-47, 2003.2

17) Zhuguo Li, Taka-aki Ohkubo, and Yasuo Tanigawa: Flow performance of high fluidity concrete, Journal of Materials in Civil Engineering, American Society of Civil Engineering, Vol.16, No.6, pp.588-596, 2004.12

18) Zhuguo Li, Taka-aki Ohkubo, and Yasuo Tanigawa: Theoretical analysis of time-dependence and thixotropy of high fluidity concrete, Journal of Materials in Civil Engineering, American Society of Civil Engineering, Vol.16, No.3, pp.195-201, 2004.6.

19) 山田義智・富山潤 : 確率過程論を用いたセメントペーストの流動曲線予 測，日本建築学会大会学術講演梗概集(中国), A-1, pp.717-718, 2008.9

20) Zhuguo $\mathrm{Li}$, Jieyong $\mathrm{Li}$, and Wenbo Zhang: Mechanical responses of freshly mixed cementitious materials to small and slow shear deformation, Proceedings of the Japan Concrete Institute, Vol. 31, No.1, pp. 1441-1446, 2009.

21) 村山朔郎：土の力学挙動の理論, 技報堂出版, pp.27-375, 1990 .

22）李柱国・飯高稔: モデル材料を用いた可視化実験によるフレッシュコン クリートの粒状体特性の解明, 日本建築学会中国支部研究発表報告集, Vol.32, No.109, pp.1-4, 2009.3.

（2009年12月23日原稿受理，2010年 4 月12日採用決定） 